\title{
CHANGE OF VENUE IN ABSENCE OF PERSONAL JURISDICTION UNDER 28 U.S.C. 1404(a) AND 1406(a)
}

No cause, proceeding or appeal should be dismissed, rejected, or thrown out solely because brought in or taken to the wrong court or wrong venue, but if there is one where it may be brought or prosecuted, it should be transferred thereto and go on there, all prior proceedings being saved.1

This proposal for reform urged in 1910 by Dean Roscoe Pound appears to have anticipated recent developments in federal court practice concerning venue and personal jurisdiction. ${ }^{2}$ Prior to 1948 , a plaintiff bringing suit in a district where venue was improper suffered dismissal of his action upon timely objection by the defendant. ${ }^{3}$ Indeed, even when venue was proper, the action could be dismissed under the doctrine of forum non conveniens, following recognition of that doctrine by the Supreme Court in 1947.4 The resultant

1 Pound, Some Principles of Procedural Reform, 4 ILL. L. REv. 491, 497 (1910).

2 It is important to distinguish between personal and subject matter jurisdiction. "Without [subject matter] jurisdiction the court cannot proceed at all in any cause. Jurisdiction is power to declare the law, and when it ceases to exist, the only function remaining to the court is that of announcing the fact and dismissing the cause." Ex parte McCardle, 74 U.S. (7 Wall.) 506 (1868). A party cannot by consent or waiver confer subject matter jurisdiction upon a federal court. Neirbo Co. v. Bethlehem Shipbuilding Corp., 308 U.S. 165 (1939); 1 MoORe, Federal Practice T 0.60(4), at 608 (2d ed. 1961) [hereinafter cited as Moore]. A court without subject matter jurisdiction will not consider a motion to transfer a cause under $\$ 1404(\mathrm{a})$ or $\$ 1406$ (a). E.g., Atlantic Ship Rigging Co. v. McLellan, 288 F.2d 589 (3d Cir. 1961); First Nat'l Bank v. United Air Lines, 190 F.2d 493, 496 (7th Cir.), cert. denied, 341 U.S. 903 (1951), rev'd on other grounds, 342 U.S. 396 (1952).

However, personal jurisdiction is required only so that the court may render a valid judgment. Lack of proper service of process may be waived and a defendant may always confer personal jurisdiction upon the court by appearing and answering in the action without first making a timely objection to the absence of personal jurisdiction. 2 MOORE $\mathbb{1} 12.12$, at $2260-64$.

For the important distinction between improper venue and lack of personal jurisdiction, see the discussion in Robertson v. Railroad Labor Bd., 268 U.S. 619 (1925).

${ }^{3}$ E.g., Camp v. Gress, 250 U.S. 308 (1919); see also HART \& WechsLeR, The Federal COURTS AND THE FEDERAL SySTEM 950 (1953) [hereinafter cited as HART \& WeCHSLER]; 1 MOORE T 0.146(2), at 1904.

4 Gulf Oil Corp. v. Gilbert, 330 U.S. 501 (1947); Koster v. Lumbermen's Mut. Cas. Co. 330 U.S. 518 (1947). "The principle of forum non conveniens is simply that a court may resist imposition upon its jurisdiction even when jurisdiction is authorized by the letter of the general venue statute." Gulf Oil Corp. v. Gilbert, supra, at 507. On the doctrine of forum non conveniens generally see Barrett, The Doctrine of Forum Non Conveniens, 35 CALIF. L. REV. 380 (1947); Blair, The Doctrine of Forum Non Conveniens in Anglo-American Law, 29 Colum. L. Rev. 1 (1929); Braucher, The Inconvenient Federal Forum, 60 HARv. L. Rev. 908 (1947); Dainow, The Inappropriate Forum, 29 ILL. L. Rev. 867 (1935); Foster, Place of Trial in Civil Actions, 43 HaRv. L. REv. 1217 (1930); Foster, Place of Trial-Interstate Application of Intrastate Methods of Adjustment, 44 HARv. L. Rev. 41 (1930). 
hardship from these dismissals was mitigated by congressional action in 1948 when sections 1404(a) (Change of Venue) 5 and 1406(a) (Cure or Waiver of Defects) 6 were included in the Judicial Code. ${ }^{7}$ These provisions authorized transfers at the discretion of the district courts when the forum was found to be an inconvenient place for trial or when venue was defective. This statutory policy of avoiding dismissal on procedural grounds and achieving a determination on the merits ${ }^{8}$ was judicially expanded in 1962 by the Supreme Court in Goldlawr, Inc. v. Heiman. ${ }^{9}$ The Court, ignoring a previous dictum, ${ }^{10}$ held that section 1406(a) authorized transfer of a case in which both venue and personal jurisdiction were defective. The decision raises questions concerning the relative importance of venue and personal jurisdiction in determining the proper place for trial within the federal judicial system.

A central issue is whether the decision foreshadows the relegation of service of process, which is of primary importance in establishing state court jurisdiction, to a relatively minor role in federal practice. $11 \mathrm{~A}$ recent district

528 U.S.C. $\$ 1404(a)$ (1958): "For the convenience of parties and witnesses, in the interest of justice, a district court may transfer any civil action to any other district or division where it might have been brought." This statute is generally regarded as a codification of the doctrine of forum non conveniens except that transfer is substituted for dismissal and transfer is authorized on a lesser showing of inconvenience. See revisor's notes to 28 U.S.C. $\S 1404$ (1958): "Subsection (a) was drafted in accordance with the doctrine of forum non conveniens, permitting transfer to a more convenient forum even though venue is proper." See also Norwood v. Kirkpatrick, 349 U.S. 29 (1955); Ex parte Collett, 337 U.S. 55 (1949).

628 U.S.C. $\$ 1406$ (a) (1958): "The district court of a district in which is filed a case laying venue in the wrong division or district shall dismiss, or if it be in the interest of justice, transfer such case to any district or division in which it could have been brought." This section incorporates into federal practice a procedure familiar in state courts that permits transfer in lieu of dismissal for improper venue. E.g., IlL. REv. STAT. ch. 110, § 8(1) (1961): "No action shall abate or be dismissed because commenced in the wrong venue or court if there is a proper venue or court of competent jurisdiction to which the cause may be transferred."

7 The adoption of these sections was widely acclaimed by various commentators. E.g. "This provision [ $\$ 1404(\mathrm{a})$ ] is like a breath of fresh air in a musty room. At last after 160 years, a start has been made towards a rational scheme of statutory venue." Blume, Place of Trial in Civil Cases, 48 MrCH. L. Rev. 1, 39 (1949); see also Kaufman, Observations on Transfers Under Section 1404(a) of the New Judicial Code, 10 F.R.D. 595 (1951); Maris, New Judicial Code: Enactment by 80th Congress a Notable Gain, 34 A.B.A.J. 863, 963 (1948).

8 Progress in this direction has not been uninterrupted. In 1960 in Hoffman v. Blaski, 363 U.S. 335 (1960), the Court gave what Mr. Justice, Frankfurter called the "narrowest possible application to the language of section 1404(a)" by holding that the phrase "where it might have been brought" refers to the time when the suit was originally filed. This interpretation bars a defendant from waiving improper venue or service of process when making a motion for transfer, and restricts the choice of transferee districts to those where venue would have been proper and service of process likely at the time the suit was instituted.

9369 U.S. 463 (1962) (Harlan and Stewart J.J., dissenting).

10 In Graham v. Bhd. of Locomotive Firemen \& Enginemen, 338 U.S. 232, 235 (1949), the Court stated: "Moreover, its [the district court's] decision transferred the cause [under $\S 1406$ (a)] to the Northern District of Ohio, a power which it could exert only if it considered the service adequate to confer jurisdiction of the parties."

11 This view was supported by Mr. Justice Jackson in 1945 when he wrote that where trial in a given state would be otherwise appropriate: "I see no reason why fortuitous circum- 
court decision suggests this possibility. In Hydrotherm, Inc. v. Bastian-Morley Co., 12 in response to defendant's motion to dismiss for improper venue and insufficiency of service of process, the court transferred the action under section 1406(a). The judge declared:

It must now be unimportant to decide whether a corporation is amenable to suit in one or another district; if it is incorporated in a state of the United States, it is suable in some district court and federal [subject matter] jurisdiction having been invoked, all that remains is to ascertain the appropriate district; Goldlawr . . . ought to make that clear. ${ }^{13}$

The purpose of this comment is to evaluate this treatment of service of process; to consider the appropriate standards under different venue statutes for the granting of section 1406(a) transfers by a court in which venue and personal jurisdiction are defective; and to explore the applicability of Goldlawr to transfers under section 1404(a) when venue is proper but personal jurisdiction is defective.

\section{The Goldlawr Decision}

Goldlawr involved a treble damage suit against multiple corporate and individual defendants brought under Sections 1 and 2 of the Sherman Act ${ }^{14}$ and Section 4 of the Clayton Act ${ }^{15}$ in the Eastern District of Pennsylvania. Venue and jurisdiction were based upon Section 12 of the Clayton Act, pursuant to which extraterritorial service of process upon several of the corporate defendants was made in New York. ${ }^{16}$ These defendants appeared specially and moved to dismiss the action for lack of personal jurisdiction and for improper venue. The court found venue and personal jurisdiction to be improper, but rather than dismissing the action it invoked section 1406(a) and transferred the cause to the Southern District of New York where venue was proper and the defendants amenable to service of process. 17 The New York court then dismissed the

stances concerning service of process should preclude an intelligent determination of venue." Jackson, Full Faith and Credit-The Lawyer's Clause of the Constitution, 45 Colum. L. REv. 1, 24 (1945).

12207 F. Supp. 744 (E.D.N.Y. 1962).

13 Id. at 745.

1426 Stat. 209 (1890), as amended, 15 U.S.C. $\S \S 1,2$ (1958).

1538 Stat. 731 (1914), 15 U.S.C. $\$ 15$ (1958). The suit was commenced within one year after entry of a consent judgment in a government antitrust action pursuant to the requirements of 69 Stat. 283 (1955), 15 U.S.C. § 16(b) (1958).

1638 Stat. 736 (1914), 15 U.S.C. $\$ 22$ (1958) provides: "Any suit, action, or proceeding under the antitrust laws against a corporation may be brought not only in the judicial district whereof it is an inhabitant, but also in any district wherein it may be found or transacts business; and all process in such cases may be served in the district of which it is an inhabitant, or wherever it may be found."

17 Goldlawr, Inc. v. Shubert, 169 F. Supp. 677 (E.D. Pa, 1958); Record, p. 46, Goldlawr, Inc. v. Heiman, 369 U.S. 463 (1962). 
action on the ground that the Pennsylvania court, in the absence of personal jurisdiction, had no power to order the transfer. 18 On review, 19 the Second Circuit affirmed the dismissal with one judge dissenting. 20 Certiorari was granted because of a conflict among circuits.21

In reversing the dismissal and approving the transfer the Supreme Court concluded that neither the language nor the legislative history of section 1406(a) indicated an intent to limit its applicablity to actions where the transferor court has personal jurisdiction. 22 Policy considerations motivated the Court:

The problem which gave rise to the enactment of the section was that of avoiding the injustice which had often resulted to plaintiffs from dismissal of their actions merely because they had made an erroneous guess with regard to the existence of some elusive fact of the kind upon which venue provisions often turn. ... If by reason of uncertainties of proper venue a mistake is made, Congress by the enactment of $\S 1406(\mathrm{a})$, recognized that "the interests of justice" may require that the complaint not be dismissed, but rather that it be transferred in order that plaintiff not be penalized by ... "time consuming and justice-defeating technicalities."23

18 Goldlawr, Inc. v. Shubert, 175 F. Supp. 793 (S.D.N.Y. 1959).

19 Appeal was originally taken under Rule 54(b) of the Federal Rules of Civil Procedure, but the appeal was dismissed for want of appellate jurisdiction. However, the case was remanded and appeal was allowed under 28 U.S.C. \$1292(b) (1958) (Interlocutory Appeals Act). The various circuits differ on the proper method of review and on whether review is possible after an order granting or denying transfer. Although the Supreme Court has heard cases on mandamus, Hoffman v. Blaski, 363 U.S. 335 (1960); Norwood v. Kirkpatrick, 349 U.S. 29 (1955); Ex parte Collett, 337 U.S. 55 (1949), and under $\$ 1292$ in the Goldlawr case, it has never passed on the proper method of review. For a discussion of the various methods of review and lower court holdings see 1 MOORE If 0.147, at 1961-75; Kaufman, Further Observations on Transfers Under Section 1404(a), 56 Colum. L. Rev, 1, 1-10 (1956); Massington, Venue in the Federal Courts-The Problem of the Inconvenient Forum, 15 U. Miami L. Rev. 237, 252-57 (1961).

20 Goldlawr, Inc. v. Heiman, 288 F.2d 579 (2d Cir. 1961). This decision and prior cases involving transfers under $\$ 1404(a)$ and $\$ 1406(a)$ are discussed in Comment, 61 CoLUM. L. REv. 902 (1961); Comment, 1962 WIs. L. REv. 342.

21369 U.S. at 465 . The Court cited Hayes v. Livermont, 279 F.2d 818 (D.C. Cir. 1960); Amerio Contact Plate Freezers, Inc. v. Knowles, 274 F.2d 590 (D.C. Cir. 1960); Orion Shipping \& Trading Co. v. United States, 247 F.2d 755 (9th Cir. 1957); Internatio-Rotterdam, Inc. v. Thomsen, 218 F.2d 514 (4th Cir. 1955). The Court neglected to mention Hohensee v. News Syndicate, Inc., 286 F.2d 527 (3d Cir. 1961), vacated and remanded, 369 U.S. 659 (1962) (per curiam, on authority of Goldlawr). This case was cited in the court of appeals decision in Goldlawr, and held that a court without personal jurisdiction was powerless to effect a transfer under $\$ 1406$ (a).

22 For legislative history of $\$ 1406$ (a), see 2 U.S. CODE CONG. SERVICE, 81sT Cong., 1sT SEss. 1949, 1248, 1253; Hearings before House Committee on the Judiciary on H.R. 1600 and H.R. 2055, 80th Cong., 1st Sess. 29 (1947); Goldlawr, Inc. v. Heiman, 288 F.2d 579 (2d Cir. 1961); Comment, 1962 WIs. L. Rev. 342, 348.

23369 U.S. at $466-67$. 
The Court stressed that dismissal in this case would deprive plaintiff of a substantial part of its cause of action since the statute of limitations had run. ${ }^{24}$

Mr. Justice Harlan in dissent argued against the majority's position on three grounds: (1) that "the notion that a district court may deal with an in personam action in such a way as possibly to affect a defendant's substantive rights without first acquiring jurisdiction over him is not a familiar one in federal jurisprudence . . . ."25; (2) that it was incongruous that a similar statutory remedy was not provided in a case where venue was proper but personal jurisdiction was defective; and (3) that Miner v. Atlass ${ }^{26}$ supported the proposition that the statutory nature of venue and personal jurisdiction required that the transfer question be submitted to the Judicial Conference for study and appropriate recommendations for congressional action. 27

\section{STATUTORY BACKGROUND}

Historically, concepts of venue and personal jurisdiction in the federal courts have been strictly regulated by statute. The Judiciary Act of 178928 remains the basis of present day venue requirements. This act divided the new nation into thirteen districts and provided that "no person shall be arrested in one district for trial in another, in any civil action.... And no civil suit shall be brought.... against an inhabitant of the United States, by any original process in any other district than that whereof he is an inhabitant, or in which he shall be found at the time of serving the writ."29 The common-law distinction between local and transitory actions was incorporated into this statute, ${ }^{30}$ with the result that the home state of a defendant was the only available forum for trial unless he entered another district. A significant change was made in 1887 when the place of trial of diversity actions was expanded to include "the district of the residence of either the plaintiff or the defendant." The same act eliminated the provision permitting trial in a district where the defendant was found. 31 Thus in nondiversity suits the place of trial was limited to the residence of the defendant. These venue requirements remained substantially unchanged and are now incorporated in section 1391 of the Judicial Code.32

24369 U.S. at 466. Suit was brought within the time permitted by the New York statute of limitations, but there was a two-year time lag before the Pennsylvania court decision that it lacked personal jurisdiction over the defendants. On the causes of this delay, see note 63 infra.

25369 U.S. at $467-68$.

26363 U.S. 641,650 (1960).

27369 U.S. at 468.
281 Stat. 73-93 (1789).

291 Stat. 79 (1789).

30 Blume, supra note 7, at 34-39.

3124 Stat. 552-53 (1887), as corrected, 25 Stat. 433 (1888).

3228 U.S.C. $\$ 1391$ (1958): “(a) A civil action wherein jurisdiction is founded only on 
Requirements for service of process are based on a separate 1789 statute which provided: "That until further provision shall be made, and except where by this act or other statutes of the United States is otherwise provided, the forms of writs and executions, ... in suits at common law, shall be the same in each state respectively as are now used or allowed in the supreme courts of the same." 33 The power granted to make exceptions to this general rule has been sparingly exercised by Congress. An act in 1793 provided that witnesses might be subpoenaed in any district, but not more than one hundred miles from the place of trial.34 In 1797, executions upon judgments for the use of the United States were authorized in states other than that of the court issuing the writ, 35 and in 1826 all writs of execution were permitted to run in all districts within the state of the issuing court. 36 Service of notice outside the state was authorized in 1875 for actions in rem and quasi in rem, 37 although this notice did not subject a party to the in personam jurisdiction of the court. These provisions remained in effect until the adoption of the Federal Rules of Civil Procedure in 1938. Rule 4(f) maintained the basic policy of restricting service of process "within the territorial limits of the state in which the district court is held."'38 This restriction, however, was modified by holdings that rule 4(d)(7) authorized service of process outside the state in accordance with state law. 39 This method was explicitly authorized by the 1963 amendments to Rules $4(\mathrm{e})$ and $4(\mathrm{f}) .40$ These amendments reflect a major departure

diversity of citizenship may, except as otherwise provided by law, be brought only in the judicial district where all plaintiffs or all defendants reside.

"(b) A civil action wherein jurisdiction is not founded solely on diversity of citizenship may be brought only in the judicial district where all defendants reside, except as otherwise provided by law.

"(c) A corporation may be sued in any judicial district in which it is incorporated or licensed to do business or is doing business, and such judicial district shall be regarded as the residence of such corporation for venue purposes ...."

331 Stat. 93 (1789).

341 Stat. 335 (1793).

364 Stat. 184 (1826).

351 Stat. 515 (1797).

3718 Stat. 139 (1875).

38 FED. R. CIV. P. 4(f). "Territorial Limits of Effective Service. All process other than a subpoena may be served anywhere within the territorial limits of the state in which the district court is held and, when a statute of the United States so provides, beyond the territorial limits of that state ...."

39 Farr \& Co. v. Cia. Intercontinental de Nav. de Cuba, 243 F.2d 342, 347 (2d Cir. 1957); Kappus v. Western Hills Oil, Inc., 24 F.R.D. 123 (E.D. Wis. 1959) (dictum); Star v. Rogalny, 162 F. Supp. 181, 183 (E.D. Ill. 1957).

40 FED. R. CIV. P. 4(e) provides: "Whenever a statute or rule of court of the state in which the district court is held provides (1) for service of a summons, or of a notice, or of an order in lieu of summons upon a party not an inhabitant of or found within the state, or (2) for service upon or notice to him to appear and respond or defend in an action by reason of the attachment or garnishment or similar seizure of his property located within the state, service may in either case be made under the circumstances and in the manner prescribed in the statute or rule."

Under Rule 4(f) as amended, service of process is effective regardless of state lines within 
from the historic policy of restricting service of process to places within the boundaries of the state in which the district court sits.

Although the general policy of strictly limiting venue and service of process has remained intact since 1789,41 Congress in the past fifty years has often enacted special venue and service of process provisions that supplant the general requirements in order to allow trial in a more convenient location. 42 Thus service of process frequently has not been limited by state lines. It has long been recognized that Congress has the power to provide for nationwide service of process ${ }^{43}$ and this power has been exercised in several restricted situations. ${ }^{44} \mathrm{It}$ is against this background of piecemeal statutory expansion of a restrictive general policy that sections 1404(a), 1406(a), and the Goldlawr decision must be evaluated.

\section{Power of a Court To Order Transfer}

In evaluating the power of a court without personal jurisdiction to transfer an action, a convenient starting place is Mr. Justice Harlan's statement that the substantive rights of the defendant were violated. 45 The thrust of this statement is not directed to constitutional limitations, but to the absence of statutory authority for the transfer order. In Goldlawr the running of the statute of limitations would have barred the suit in the proper forum if the action had been dismissed. Thus, the decision to transfer may change the end result of the litigation. There is no doubt that this is prejudicial to the defendant, but the question remains whether section 1406(a) authorizes a court to affect the defendant's "rights."

In speaking of substantive rights Mr. Justice Harlan appears to be relying on the traditional distinction between the rights and duties creating a cause of action as opposed to the machinery for carrying on the litigation. 46 This distinction between substance and procedure has been criticized by courts and

a hundred mile radius from the court house in certain specified situations. The rule is operative to bring in persons impleaded (Rule 14), those who are required for a cross or counter claim (Rule 13(h)), or those who are parties to a pending action (Rule 19). The rule appears salutary in its stress on proximity of the parties to the place of trial in lieu of artificial barriers imposed by state lines, but the practical effect of the change will be seriously limited by the retention of traditional venue requirements.

41 It is significant to note that until 1887 the requirements of service of process and venue were substantially identical. See HART \& WECHSLER 948.

42 These statutes are collected in a table in 1 MOORE $10.144(17)$, at 1680-85.

43 Cf. Mississippi Publishing Corp. v. Murphree, 326 U.S. 438, 442 (1946); Robertson v. Railway Labor Board, 268 U.S. 619, 622 (1925); United States v. Union Pac. R.R., 98 U.S. 569, 604 (1878); Toland v. Sprague, 37 U.S. (12 Pet.) 300, 328 (1838).

44 E.g., 28 U.S.C. $\$ 1391($ e) (1962) (providing for nationwide service of process in suits against Government officials).

45 See text at note 25 supra.

46 Jones v. Erie R.R., 106 Ohio St. 408,140 N.E. 366 (1922). See also LLEWELLYN, ThE BRAMBLE Bush 16-18 (1960 ed.). 
commentators as unsatisfactory 47 since it does nothing more than state a conclusion. In most cases there are elements that cannot be classified as either procedural or substantive and consequently the courts have been required to make a choice between preserving the rights of a party and utilizing a particular statute or rule that is designed to facilitate the machinery of adjudication. In making the choice the relevant inquiry should be whether the right allegedly transgressed is one entitled to judicial protection.

This approach was followed in Internatio-Rotterdam, Inc. v. Thomsen 48 where the court allowed transfer of an admiralty action despite an absence of personal jurisdiction in the transferor court. The court stated:

It is argued that no order transferring the cause can be entered until jurisdiction has been acquired by service of process in an action in personam .... This argument fails, however, to distinguish between acquiring jurisdiction over the proceedings commenced before the court and acquiring jurisdiction over the person .... Certainly the court has no power to enter judgment against person or property until process has been duly served ... but it by no means follows that it is without power to enter orders in the cause which are necessary to the maintenance of the litigation itself. 49

The Supreme Court cited this case as contrary to the court of appeals decision in Goldlawr,50 even though technically the case can be distinguished from the Goldlawr situation. In admiralty a libel in rem may be filed in a district in which there is a port at which the ship is expected to return. This filing satisfies the one year statute of limitations. Since the ship often does not return to the anticipated port, it has been a traditional power of admiralty courts to transfer the action to the district where the ship can be found.51 Although the in rem aspects of an admiralty action were not present in Goldlawr, the policy of employing transfer to preserve the cause of action is applicable in both situations.

47 Guaranty Trust Co. v. York, 326 U.S. 99, 108 (1945); Sibbach v. Wilson \& Co., 312 U.S. 1, 17 (1941) (Frankfurter, J., dissenting); Kellman v. Stoltz, 1 F.R.D. 726 (N.D. Iowa 1941); Clark, Procedural Aspects of the New State Independence, 8 GEO. WASr. L. REv. 1230, 1234 (1940): "[N]o abstract and formal differentiation between substance and procedure is possible. In fact almost any borderline case will necessarily present elements both substantive and procedural in nature ...."; Cook, "Substance" and "Procedure" in the Conflict of Laws, 42 YALE L.J. 333, 336 (1933).

48218 F.2d 514 (4th Cir. 1955).

49 Id. at 516.

so See note 21 supra and accompanying text.

51 Goldlawr, Inc. v. Heiman, 288 F.2d 579, 585 (2d Cir. 1961); Internatio-Rotterdam, Inc. v. Thomsen, 218 F.2d 514, 515-16 (4th Cir. 1955). This distinction was used by the Supreme Court in 1960 to exempt an admirality action from the requirement of $\S 1404$ (a) that the transferor district must be one where the action could have been brought initially. Continental Grain Co. v. Barge FBL-585, 364 U.S. 19 (1960); see also note 8 supra. 
A similar approach was followed by the Supreme Court in response to a contention that Rule 4(f) of the Federal Rules of Civil Procedure (Territorial Limits of Effective Service) 52 violated a congressional mandate that the new rules of practice for the district courts "shall neither abridge, enlarge, nor modify the substantive rights of any litigant." 53 The Court rejected the argument:

Undoubtedly most alterations of the rules of practice and procedure may and often do affect the rights of litigants .... . The fact that the application of Rule 4(f) will operate to subject petitioner's rights to adjudication by the district court for northern Mississippi will undoubtedly affect those rights. But it does not operate to abridge, enlarge or modify the rules of decision by which the court will adjudicate its rights. It relates merely to "the manner and means by which a right to recover ... . is enforced." ... In this sense the rule is a rule of procedure and not of substantive right and is not subject to the prohibitions of the Enabling Act. 54

When a court without personal jurisdiction orders the transfer of an action it may be argued that the defendant is deprived of an alleged right to dismissal for want of personal jurisdiction. This right is particularly important when the statute of limitations has run prior to a determination that the transferor court lacks personal jurisdiction. The defendant may argue that he has been deprived of the right to impose the statute of limitations as a defense if the action is transferred rather than dismissed.

There seems to be no basis for a claim of a constitutional right to dismissal for want of personal jurisdiction. It may be suggested that since in state court proceedings the reach of the court's personal jurisdiction delimits the court's power to render a valid judgment, 55 the entry of a transfer order by a federal court where service is improper is beyond its jurisdiction and hence a violation of due process. However, this constitutional limitation upon state sovereignty is not binding upon federal courts because the source of their power is the sovereignty of the United States. ${ }^{56}$ Thus the power to allow nationwide service of process is present. If service is made within the United States, the only basis of a claim of a right to a dismissal must be found in statutory policy. 57

52 See note 38 supra.

5348 Stat. 1064 (1943), 28 U.S.C. \$2072 (1958).

54 Mississippi Publishing Corp. v. Murphree, 326 U.S. 438, 445-46 (1946).

55 See Hanson v. Denckla, 357 U.S. 235 (1958); McGee v. International Life Ins. Co., 355 U.S. 220 (1957); Perkins v. Benguet Consol. Mining Co., 342 U.S. 437 (1952); Travelers Health Ass'n v. Virginia, 339 U.S. 643 (1950); International Shoe Co. v. Washington, 326 U.S. 310 (1945).

56 See Green, Federal Jurisdiction in Personam of Corporations and Due Process, 14 VAND. L. REV. 967 (1961).

57 See note 38 supra. 
However, a substantial constitutional argument may be predicated on the due process requirement that a defendant must receive adequate notification of litigation so that he may appear and be heard. 58 A response to this is that since transfer by a court without personal jurisdiction does not obviate the necessity of a valid service of process in the transferee district59 the defendant's rights are adequately protected. However, this answer may not be adequate. In Hohensee v. News Syndicate, Inc.60 the court argued that in order to determine if transfer is in the interest of justice "both parties of necessity must at least have an opportunity to be heard. If the defendant is not in court, i.e., he has not been served or has not voluntarily appeared, how can it be said that he has had such an opportunity, for it may well be that he is totally unaware of the action." 61 The Supreme Court vacated this decision on authority of Goldlawr, but the facts reveal that the defendant had received actual notification of the action by service of process which the lower court held to be invalid on purely technical grounds.

Thus actual notice of the commencement of the action may be required when a defendant raises the objection that he has been deprived of a "right" to invoke a limitations or laches defense 62 at the transfer proceeding. The Goldlawr case provides an illustration. The defendants were wholly owned subsidiaries of the principal defendant in the Pennsylvania action. These corporations received actual notice of the action by service of process in their New York office and the statute of limitations had expired in the two years taken by the Pennsylvania court to determine that it lacked personal jurisdiction. ${ }^{63}$ The Court viewed the statute of limitations only as a means of requiring

58 Cf. Schroeder v. City of New York, 371 U.S. 208 (1962); Walker v. Hutchinson, 352 U.S. 112 (1956); Mullane v. Central Hanover Bank, 339 U.S. 306 (1950).

59 Goldlawr, Inc. v. Shubert, 175 F. Supp. 793 (S.D.N.Y. 1959); United States v. Welch, 151 F. Supp. 899 (S.D.N.Y. 1957); cf. Hoffman v. Blaski, 363 U.S. 335 (1960); FosterMilburn Co. v. Knight, 181 F.2d 949 (2d Cir. 1950).

60 Hohensee v. News Syndicate, Inc., 286 F.2d 527 (3d Cir. 1961), vacated and remanded, 369 U.S. 659 (1962) (per curiam, on authority of Goldlawr).

61286 F.2d at 530 .

62 The equitable doctrine of laches, not the statute of limitations, governs when a case is based on a federally created equitable right. See Holmberg v. Armbrecht, 327 U.S. 392, 396 (1946).

63 Unfortunately, a decision on an objection to personal jurisdiction or venue is often delayed. This may partially be attributed to crowded dockets and judicial workload, but the more basic reason is that obtaining an extension of time to answer and to take depositions is not a waiver of objections to defective personal jurisdiction and improper venue. E.g., Blank v. Bitker, 135 F.2d 962 (7th Cir. 1943); River Plate Corp. v. Forestal Land, Timber \& Ry. Co., 185 F. Supp. 832 (S.D.N.Y. 1960) (question of jurisdiction held in abeyance pending taking of depositions); Deep So. Oil Co. v. Metropolitan Life Ins. Co., 21 F.R.D. 340 (S.D.N.Y. 1958) (taking of depositions ordered to determine whether venue proper). 
diligence on the part of the plaintiff.64 This position may derive support from the Federal Rules of Civil Procedure which provide that an action is commenced and the statute of limitations tolled upon the filing of the complaint regardless of when service of process is had upon the defendant. 65 If this view is taken, it is, indeed, difficult to argue that any valuable right of the defendant has been violated.

It should be recognized, however, that the statute of limitations also protects defendants against stale claims. In a situation where the defendant did not receive actual notice of the commencement of the suit until long after the expiration of the statute of limitations he may well have a judicially protected right to dismissal of the action. The language of section 1406(a) requiring dismissal of the action when the court finds that transfer would not be "in the interest of justice"66 may require that a defendant be given actual notification of the proceeding so that he may appear and resist the transfer. ${ }^{67}$ Dismissal would be fully justified when a defendant has not been notified until after the expiration of the statute of limitations or when the plaintiff is attempting to take unfair advantage of the limitations statute. 68 Throughout the Goldlawr opinion it is stressed that the plaintiff was proceeding in good faith. It is submitted that a finding to this effect should be a prerequisite to a transfer order.

An excellent example of an undeserving plaintiff who suffered a dismissal may be found in Skilling $v$. Funk Aircraft C 0.69 In that case a court without personal jurisdiction held that transfer of an action brought one day prior to the expiration of the statute of limitations would not be "in the interest of

64 "When a lawsuit is filed, that filing shows a desire on the part of the plaintiff to begin his case and thereby toll whatever statute of limitations would otherwise apply. The filing itself shows the proper diligence on the part of the plaintiff which such statute of limitations was intended to insure." 369 U.S. at 467.

65 Fed. R. Crv. P. 3.

66 For factors used in determining "the interest of justice," see 1 MOORE $\lceil 0.145(5)$, at 1777-87, T1 0.146(5), at 1906-10.

67 It can be argued that since the defendant may have an adequate opportunity to raise these objections in proceedings in the transferee court, he thus is fully protected. However, since efficient judicial administration requires that the determination of the transferor court that transfer is "in the interest of justice" be conclusive in the transferee district, notice prior to transfer would seem necessary.

68 The obvious problem of forum shopping in order to avoid the statute of limitations in the proper district is not significant when the transferor court lacks personal jurisdiction. The transferor court cannot proceed to a valid judgment and thus must apply the statute of limitations of the transferee district. If the statute of limitations has expired in the proper district, "the interest of justice" requires that the action be dismissed. However, if the limitations period has not expired in the appropriate district or if it expires during the pendency of the litigation, there appears to be no reason why the statute should not be considered as tolled when the action was commenced if all the other prerequisites for transfer are met. See Comment, 61 Colum. L. REv. 902, 914-17 (1961); see also, B. Currie, Change of Venue and the Conflict of Laws, 22 U. CkI. L. REv. 405 (1955); B. Currie, Change of Venue and the Conflict of Laws: A Retraction, 27 U. CHI. L. REv. 341 (1960).

69173 F. Supp. 939 (W.D. Mo. 1959). 
justice." The plaintiff had made no attempt to serve the defendant in the forum state and made no showing that the defendant had ever transacted business in that state. It was obvious to the court that the only reason that the action was commenced was to toll the statute of limitations. The dismissal seems completely justified.70 There is no suggestion in section 1406(a) or in its legislative history that a party may abrogate his responsibility to bring suit in a proper district by relying upon the courts to channel the litigation to the proper location.

It would seem, therefore, that a district court without personal jurisdiction has the power to transfer an action, but that this power is modified by the statutory requirement that transfer be "in the interest of justice." This requires a finding in each case that the plaintiff is proceeding in good faith and that the defendant had adequate opportunity to resist the transfer proceedings. The statement of the court in Hydrotherm, Inc. v. Bastian-Morley Co.71 that "it must now be unimportant to decide whether a corporation is amenable to suit in one or another district" 72 overlooks the importance of these two tests. Under the Goldlawr decision transfer should be limited to a relatively few cases in which the court finds that lack of personal jurisdiction is caused by a miscalculation made in good faith that the party was amenable to an effective service of process.

\section{ApPlication to DiverstTy and Federal Question Cases}

In Goldlawr personal jurisdiction and venue were based upon provisions in the Clayton Act ${ }^{73}$ and the plaintiff noted various other special statutes where venue provisions are generally indistinguishable from jurisdictional requirements. 74 The congressional purpose in enacting such provisions, many of

70 This action is fully supported by the legislative history of $\S 1406(a)$. The statute originally read: "The district court of a district in which is filed a case laying venue in the wrong division or district shall transfer such case to any district or division in which it could have been brought.' It is thought that this provision may be subject to abuse in that a plaintiff might deliberately bring a suit in the wrong division or district where he could get service on the defendant, and when the question of venue is raised the court is required to transfer the case to a court where it 'could have been brought.' However, in the meantime, service has been perfected on a defendant in the wrong venue, and it will carry over into the new (and proper) venue. Rather than promoting justice, it can be seen that this section may be subject to abuse....." 2 U.S. Code Cong. Service, 81st Cong., 1st Sess. 1949, 1248, 1253.

71207 F. Supp. 744 (E.D.N.Y. 1962).

$72 \mathrm{Id}$. at 745.

73 See note 15 supra.

74 Petition for Certiorari, p. 8, Goldlawr, Inc. v. Heiman, 369 U.S. 463 (1962), cited the following statutes which permit suit in a district wherein the defendant is found or transacts business: (a) actions for recovery of fines, penalties or forfeitures, 28 U.S.C. $\$ 1395$ (1958); (b) actions under the Securities Act of 1933, 48 Stat. 86 (1933), 15 U.S.C. $\$ 77 \mathrm{v}$ (1958); (c) actions under the Copyright Act, 28 U.S.C. $\$ 1400$ (a) (1958); (d) actions under the Securities Exchange Act of 1934, 48 Stat. 902 (1934), 15 U.S.C. § 78aa (1958); (e) actions under the Public Utility Holding Company Act, 48 Stat. 835 (1936), 15 U.S.C. $\$ 79$ y (1958); 
which in addition provide for liberalized methods of service of process, was to facilitate litigation. The Goldlawr decision certainly advances this policy. However, the applicability of the Goldlawr principle would also seem to extend to cases arising under the general federal question venue provisions and to diversity cases where the statutory policy favoring expedited litigation is not present.

In federal question cases under section 1391(b) venue is proper only in the district where all the defendants reside. ${ }^{75}$ Section 1406 (a) may be utilized in cases where the plaintiff makes a good-faith mistake as to the residence of the defendant under section 1391 (b), but the transfer provision is more likely to be invoked when a plaintiff is mistaken about whether a corporation is doing business in a particular jurisdiction within the meaning of section 1391(c)..$^{76}$ As in Goldlawr, a mistake about the proper corporate venue is also likely to result in failure to obtain personal jurisdiction. Although there is no strong congressional indication that the suit should be facilitated, there appears to be no reason why the same result should not follow. If the suit is brought in good faith and if the defendant is not surprised by the claim long after the statutory period of limitations has expired in the proper forum, the rights of the defendant are adequately protected when the court finds that transfer is in the "interest of justice." There does not seem to be any reason why the plaintiff should not be permitted to have his claim decided upon its merits.

A different situation is presented in cases based upon diversity of citizenship. The very existence of diversity jurisdiction in the federal courts is a source of controversy 77 as is the question whether the doctrine expressed in Erie R.R. v. Tompkins ${ }^{78}$ has a constitutional basis. ${ }^{79}$ The view on the broad issue of the scope and purpose of diversity jurisdiction may determine whether transfer of a diversity case by a court without personal jurisdiction is allowed.

(f) actions under the Investment Companies Act, 54 Stat. 844 (1940), 15 U.S.C. \$80a-43 (1958); (g) actions under the Automobile Dealer's Act, 70 Stat. 1125 (1956), 15 U.S.C. $\$ 1222$ (1958); (h) actions under the Taft-Hartley Act, 72 Stat. 945 (1958), 29 U.S.C. $\S 160 \mathrm{e}$, f (1958), 62 Stat. 991 (1947), 29 U.S.C. $\$ 160$ j (1958); (i) actions under the Federal Employers' Liability Act, 35 Stat. 66 (1908), 45 U.S.C. $\$ 56$ (1958).

75 See note 32 supra.

$76 \mathrm{Ibid}$. A similar situation presently exists when the defendant is a voluntary association, since it is unclear whether suits against such defendants are governed by 28 U.S.C. $\$ 1391$ (c) (1958), or the narrower venue provision of $\$ 1391(\mathrm{~b})$. See Rutland Ry. v. Bhd. of Locomotive Engineers, 307 F.2d 21 (2d Cir. 1962) (holding \$ 1391(c) applicable).

77 The historical and functional arguments for and against diversity jurisdiction are collected in Kurland, Mr. Justice Frankfurter, The Supreme Court and the Erie Doctrine in Diversity Cases, 67 Y ALE L.J. 187, 195-97 (1957).

78304 U.S. 64 (1938).

79 Compare Kurland, supra note 77, (urging that Erie should not be given a constitutional basis), with Hill, The Erie Doctrine and the Constitution, 53 Nw. U.L. REv. 427 (1958) (contending that the Erie doctrine is constitutional in origin). 
The Erie doctrine has been interpreted to mean that the federal court serves merely as another court of the state in which it sits. ${ }^{80}$ Although the federal court is still governed by federal procedure, the test often used by the courts in determining whether a particular federal rule should be applied is whether the application of the rule would change the outcome of the litigation. 81 However, this test is not absolute. It has been superseded when the existence of a strong federal policy has been found to outweigh the general interest in uniformity of result.82 Those who favor a limitation of diversity jurisdiction might argue that transfer is precluded in all cases when venue and personal jurisdiction are improper because a state court could not render a binding judgment and the limitations of state sovereignty preclude transfer to a forum outside the state. This argument exalts form over substance in the application of the Erie doctrine. The Rules of Decision Act expressly provides that federal statutes will prevail 83 and a statute governing venue is clearly a "housekeeping" detail in apportioning litigation among the federal courts. The Erie requirement as expressed in the outcome test is inapplicable. Thus it has been held in a diversity case that the state rule of forum non conveniens does not require dismissal of an inconveniently laid suit since Congress in section 1404(a) has explicitly legislated in this area.84 In Jaftex Corp. v. Randolph Mills, Inc.,85 the Second Circuit in a diversity case discussed whether Erie required the application of state law in determining whether a corporation was subject to its jurisdiction. For the purpose of the discussion it was assumed that the reach of the court's personal jurisdiction under the Federal Rules was broader than that provided by state statutes. The court noted that Congress had the power to provide for nationwide service of process, and maintained that the constitutional power to hear diversity cases empowers Congress and the courts to establish rules of procedure independent of state requirements. The court concluded that the federal test was applicable, a determination that clearly changed the outcome of the litigation. If

80 Guaranty Trust Co. v. York, 326 U.S. 99 (1945). The Erie doctrine has been applied to require a federal court to follow state law as to burden of proof, Cities Serv. Oil Co. v. Dunlap, 308 U.S. 208 (1939); conflict of laws, Klaxon Co. v. Stentor Elec. Mfg. Co., 313 U.S. 487 (1941); contributory negligence, Palmer v. Hoffman, 318 U.S. 109 (1943); and commencement of an action for application of the statute of limitations, Ragan v. Merchants Transfer \& Warehouse Co., 337 U.S. 530 (1949).

81 Guaranty Trust Co. v. York, supra note 80.

82 Cf. Byrd v. Blue Ridge Rural Elec. Co-op., 356 U.S. 525 (1958), discussed in The Supreme Court, 1957 Term, 72 HARv. L. REv. 77, 147 (1958).

83 "The laws of the several states, except where the Constitution or treaties of the United States or Acts of Congress otherwise require or provide, shall be regarded as rules of decision in civil actions in the courts of the United States in cases where they apply." 28 U.S.C. $\$ 1652$ (1958).

84 Willis v. Weil Pump Co., 222 F.2d 261 (2d Cir. 1955); see also MOORE, CoMmentary ON THE U.S. JUDICLAL CODE I 0.03(45), at 330-31 (1949).

85282 F.2d 508 (2d Cir. 1960). 
this practice of stressing federal procedural requirements which broaden the scope of the court's diversity jurisdiction is maintained there appears to be no reason why the Goldlawr rationale should not be fully applicable to diversity cases.

\section{EFFECT UPON SECTION 1404(a)}

The question remains whether the Goldlawr decision will have any effect on cases where venue is proper but personal jurisdiction defective. This factual situation was presented in a recent district court case. In Powell $v$. Sealectro, Inc. 86 a diversity action was brought in Connecticut by a Connecticut plaintiff against a New York defendant for breach of contract. The defendant moved for dismissal for want of personal jurisdiction. The defendant corporation maintained no property in Connecticut and was not registered to do business as a foreign corporation in that state. However, the company solicited business there through an independent manufacturer's representative that had an exclusive sales territory on a commission basis. Employees of the defendant went into Connecticut approximately six times a year to work on engineering problems and encourage sales through a sales representative. Service of process was had upon the vice-president of the defendant corporation at his Connecticut residence. The court applied federal law under the Jaftex case and found that it did not have personal jurisdiction over the defendant. The court then quoted a long passage from the Goldlawr decision mentioning section 1406(a) and concluded that "since... [the] case might well be within the purview of the doctrine advanced by the Supreme Court in Goldlawr, Inc. v. Heiman ....," the dismissal of the action should be suspended for twenty days to allow the plaintiff to file a motion for transfer. 87 The opinion made no mention of section 1404(a), even though section 1406(a) was clearly inapplicable because venue was proper.

Section 1404(a) was incorporated in the Judicial Code in 1948. The revisor's notes stated that the section "was drafted in accordance with the doctrine of forum non conveniens, permitting transfer to a more convenient forum, even though the venue is proper." 88 The Supreme Court has construed the section on three occasions. In Ex parte Collet 89 it held the section applied to all civil actions whether governed by general or special venue provisions. In Norwood v. Kirkpatrick 90 the Court ruled that Congress intended to do more than merely codify the doctrine of forum non conveniens in adopting section 1404(a) with the consequence that transfers could be granted upon a

\$6 205 F. Supp. 6 (D. Conn. 1962).

87 Id. at 9.

88 Revisor's notes to 28 U.S.C. § 1404 (1958); see note 5 supra.

s9 337 U.S. 55 (1949); see also United States v. National City Lines, Inc., 337 U.S. 78 (1949).

90349 U.S. 29 (1955). 
lesser showing of inconvenience than that required for application of forum non conveniens. In Hoffman v. Blaski ${ }^{91}$ the Court restrained its liberal approach to the statute and imposed the requirement that the transferee district be one in which venue would have been proper and the defendant available for service of process at the time the action was originally commenced.

It has been held that a plaintiff cannot move to transfer under section 1404(a),92 but the later cases, and the Supreme Court by implication, have held that plaintiffs may make such a motion. 93 However, the Hoffman limitation that the transferee district must be one where venue was proper and the defendant amenable to service of process when the action was initially commenced has all but removed the incentive for a plaintiff to move for transfer except in situations where there is an absence of personal jurisdiction in the initial forum.

Several arguments may be made against the application of section 1404(a) when the transferor court lacks personal jurisdiction. Under the section an action may be transferred "to any other district or division in which it could have been brought." It can be maintained that this language implies that jurisdiction over the person was present and the action was properly before the transferor court. However, when section 1404(a) was enacted it was contemplated that venue would be proper, while as to section 1406(a) the contemplation was that the venue would be defective. This would seem to be a sufficient reason for the language, independent of considerations of personal jurisdiction.

It has also been maintained that section 1404(a) has inherited the requirements of the doctrine of forum non conveniens, 94 and that as a consequence the section may not be used by a plaintiff when the court lacks personal jurisdiction. In this context, the Supreme Court has stated:

In all cases in which the doctrine of forum non conveniens comes into play, it presupposes at least two forums in which the defendant is amenable to process; the doctrine furnishes criteria for choice between them. 95 and

Indeed, the doctrine of forum non conveniens can never apply if there is absence of jurisdiction or mistake of venue. 96 1950).

91363 U.S. 335 (1960); see also Foster-Milburn Co. v. Knight, 181 F.2d 949 (2d Cir.

92 Barnhart v. John B. Rogers Producing Co., 86 F. Supp. 595 (N.D. Ohio 1949).

93 Troy v. Poorvu, 132 F. Supp. 864 (D. Mass. 1955); Dufek v. Roux Distrib. Co., 125 F. Supp. 716 (S.D.N.Y. 1954); cf. Hoffman v. Blaski, 363 U.S. 335 (1960). When speaking of a contention that plaintiff could not move for transfer, the Court stated: "Nothing in $\$ 1404(a)$, or in its legislative history, suggests such a unilateral objective and we should not, under the guise of interpretation, ascribe to Congress any such discriminatory purpose." Id. at 344.

94 See note 4 supra.

95 Gulf Oil Corp. v. Gilbert, 330 U.S. 501, 506-07 (1947).

$96 \mathrm{Id}$. at 504. 
This language has been used in cases which bar transfer under section 1404(a) on the basis that the transferor court lacks personal jurisdiction. 97 As long as courts follow the revisor's notes 98 and consider section 1404(a) as a forum non conveniens statute it is doubtful if transfers under this section will be allowed when personal jurisdiction is lacking. However, Norwood v. Kirkpatrick, 99 which states that "Congress in writing 1404(a), which was an entirely new section, was revising as well as codifying,"100 provides a footing for a court desiring to rid the section of the requirements of forum non conveniens. Moreover, section 1404(a) is not, strictly speaking, a forum non conveniens statute since it provides for transfer within a sovereign judicial system whereas the traditional doctrine only applied when the proper place for trial was under a different sovereign system of courts. 101

Finally, it may be argued that the legislative history of section 1404(a) signifies that transfer is not allowed in the absence of personal jurisdiction. Thus Professor James Moore, the guiding force behind adoption of section 1404(a), told the House Committee on the Judiciary in 1945 that "Both of these changes [sections 1404 and 1406] were in line with modern state practice...."102 It is true that a state court may not order a transfer outside of the state, but the statement of Professor Moore may be read as referring only to state practice as to venue, since there was no mention of the personal jurisdiction problem in either the hearings or debates. Indeed, Professor Moore supports the view that lack of effective service of process in the transferor district should not bar a transfer under section 1404(a).103

The Supreme Court has not had occasion to decide whether transfer by a

97 Viaggio v. Field, 177 F. Supp. 643, 644 (D. Md. 1959); Blackwell v. Vance Trucking Co., 139 F. Supp. 103, 110 (E.D.S.C. 1956); Wilson v. Kansas City So. Ry., 101 F. Supp. 56 (W.D. Mo. 1951) (alternative holding).

98 See note 5 supra.

99349 U.S. 29 (1955).

$100 \mathrm{Id}$. at 32.

101 B. Currie, supra note 68 , at $436-38$. "The device of change of venue is available only on the intrastate level; it is not available in the solution at the interstate or international level, which is the problem to which the doctrine of forum non conveniens is addressed. This, again, is because of the defect of power which distinguishes the interstate situation. No court has power to transfer a case to a court of another sovereign. The problems with which the doctrine of forum non conveniens deals cannot be solved by transfer, or change of venue." (Emphasis in original) Id. at 423.

102 Hearings before House Committee on the Judiciary on H.R. 1600 and H.R. 2500, 80th Cong., 1st Sess. 29 (1947).

103 1 MOORE Tf 0.145 (6.-2), at 1791: "At times [when] the plaintiff may not be able to obtain effective service of process on the defendant, he may seek a change of venue to a district where service can be obtained. If the transferor-district court has subject matter jurisdiction and the venue in the transferee-district is proper, failure of plaintiff to effect service in the transferor-district should not operate as a rigid bar to a transfer to a district where venue would be proper and service of process could be made on the defendant." See also 1 MOORE $\uparrow 0.140(4)$, at 1330-33; cf. note 11 supra. 
court without personal jurisdiction is authorized by section 1404(a). The restrictive interpretation of section 1404(a) in the Hoffman ${ }^{104}$ case may indicate that such a transfer is improper, but application of the reasoning of the Goldlawr decision suggests that the two sections should be treated alike. The legislative purpose in enacting both sections was to provide a remedy of transfer in lieu of dismissal on procedural grounds. If the two sections are similarly interpreted the incongruity suggested by Mr. Justice Harlan that no relief is provided in a case where venue is proper, but personal jurisdiction defective, would be removed and the general policy of facilitating the determination of cases on their merits would be advanced. In this respect the language of section 1404(a), like that of section 1406(a), is discretionary, and the same analysis that has been applied to suits under the latter would be applicable in determining the propriety of transfer in particular cases.

\section{CONCLUSION}

It is submitted that the Supreme Court in the Goldlawr decision has reached a desirable result in extending the clearly expressed congressional policy of avoiding dismissal for improper venue to the area of personal jurisdiction. The general policy of avoiding technicalities and reaching a determination on the merits of the controversy has been advanced. But although the Goldlawr result may be salutary, a pervasive weakness in the opinion is that legislative intent is found in congressional silence on the question of whether personal jurisdiction is a prerequisite for transfer. The result does follow a clearly defined congressional pattern of relaxing strict requirements of venue and service of process. However, it must be noted that these changes have traditionally occurred as a result of the enactment of explicit statutes. 105 The decision appears to deviate materially from this pattern. 106 The uncertainty which it has created would be reduced if the Judicial Conference of the United States were to consider this question and submit appropriate legislative proposals to Congress. However, if the courts are to depart from their previous reluctance to expand venue and service of process requirements by judicial action, consistency would seem to demand extension of the Goldlawr reform to cases arising under section 1404(a).

Finally, it must be understood that the Goldlawr decision does not work a

104 See note 8 supra.

105 See text following note 41 supra.

$105 C f$. Miner v. Atlass, 363 U.S. 641, 650-52 (1960). Compare also the statement of Mr. Justice Black (the author of the Goldlawr opinion) and Mr. Justice Douglas on the Rules of Civil Procedure and the Proposed Amendments, Jan. 21, 1963, p. 31. (83 Sup. Ct. No. 7, Feb. 1, 1963): "We believe that while some of the Rules of Civil Procedure are simply housekeeping details, many determine matters so substantially affecting the rights of litigants in law suits that in practical effect they are the equivalent of new legislation which in our judgment, the Constitution requires to be initiated in and enacted by the Congress and approved by the President." 
major change in the importance of personal jurisdiction in the federal courts. It does not signify that once a suit is instituted in a federal court it is immune from dismissal for want of personal jurisdiction. We have not reached the point of nationwide service of process. It must always be kept in mind that the application of the Goldlawr rule requires that a court without personal jurisdiction consider whether the plaintiff is proceeding in good faith and whether a transfer would be in the "interest of justice." Actual notice of the commencement of the litigation should be an important factor in determining whether transfer would deprive the defendant of a legitimate defense such as the statute of limitations. As a minimum, findings that the plaintiff was proceeding in good faith and that transfer is in the "interest of justice" should be required for issuance of a transfer order. 